


\title{
Education and Nonmetropolitan Income Growth in the South
}

\author{
Mark Henry \\ Department of Applied Economics and Statistics, Clemson University, \\ Clemson, SC 29634, \\ e-mail:mhenry@clemson.edu \\ David Barkley \\ Department of Applied Economics and Statistics, Clemson University, \\ Clemson, SC 29634, \\ e-mail:dbrkly@clemson.edu

\section{Haizhen Li} \\ Department of Applied Economics and Statistics, Clemson University, \\ Clemson, SC 29634, \\ e-mail:Ihaizhe@clemson.edu
}

\begin{abstract}
This research evaluates the effects of higher stocks of human capital (measured by the share of adults with some college) on growth in county per capita income using a Mankiw, Romer, and Weil type model adjusted for spatial dependence and capital stocks. Regressions based on county data from the 1970-2000 censuses for the 15 southern states indicate that metro counties realized more of a "growth premium" from added human capital than nonmetro counties. With nonmetro counties, service-based counties generally fared best from enhanced human capital.
\end{abstract}

Keywords: Human capital; County income growth; Nonmetropolitan South; Economic base

JEL classification: $R 11$; I21 


\section{INTRODUCTION}

The role of education in local, regional, and national economic development and how to finance schools have become central public policy issues in recent years. School finance is one of the most widely debated public policy issues across all levels of government. Much of this debate, in the post-Serrano era, has focused on ways and needs to revamp funding sources - increasing the state share and reducing local shares of school funding - in attempts to "equalize" funding per student across rich and poor school districts. Recent work has focused on effects that aging of the population might have on school funding (Ladd and Murray 2001; Harris, Evans, and Schwab 2001; and Poterba 1997).

However, investigation of the linkages between improved schools and local economic development is rare. ${ }^{1}$ Rural localities in particular, which typically have lower education levels among the adult population than urban areas, may view increased educational investments as an important component of an economic development strategy. At the same time, rural communities are sensitive to the "leakage" of human capital investments to other areas with better education and job opportunities.

Improved educational attainment in a rural county may translate into a higher quality local labor force that in turn stimulates local economic development through enhanced entrepreneurial activity and labor force productivity. In addition, school quality may be important insofar as it signals prospective employers that the local labor force has good basic academic/analytical skills and will be more adaptive to new technology, thus reducing the unit labor costs to prospective employers. Alternatively, a local pool of native talent may be relatively unimportant to rural development in the South. In this view, economic growth depends not on the size and quality of the labor force in a commuting area around the rural community but on the attractiveness of the local area, especially its natural and cultural amenities. Perceived school quality is just one of those amenities, and may be critical only where natural amenities are insufficient to attract labor force from outside the region.

We assume that higher quality local schools are likely to be associated with higher levels of local human capital if, for example, areas with larger pools of residents with college degrees (or similar proxies for the stock of human capital) demand higher levels of investment in local schools. In this view, measures of educational attainment by residents of a county serve as proxies for both the quality of local schools and the stock of human capital.

Since rural counties comprise the focus of concern, models of small region growth are developed that reflect economic linkages that rural areas may have with proximate

\footnotetext{
${ }^{1}$ Barkley and Henry (1998) estimate a Carlino-Mills type model across counties of South Carolina and find a positive effect of lower pupil-teacher ratios on county population and employment growth.
} 
counties - labor commuting, for example. Many studies using Mincer-type models have documented the returns to education for individuals using micro data. In this article, we evaluate the aggregate effects of higher stocks of human capital (like share of population with college degrees) in a county on subsequent growth in real per capita income. This regional approach implies that the underlying returns to individuals who invest in human capital will result in higher aggregate per capita incomes in the county. Of course, individuals residing in a county at the time the regional stock of human capital is measured may not have remained in the county over the study period. So there is no simple aggregation over returns to human capital investments by individual residents of a county that will correspond to the observed growth in county average or per capita income. In the next section of the article, we consider several models that can be used to introduce education or, more broadly, human capital as a potential source of real income growth in the rural South.

\section{SELECTED MACRO GROWTH MODELS WITH HUMAN CAPITAL}

Incorporating human capital into macro growth models (education and/or learning by doing) falls into two main camps (see Krueger and Lindahl, 2001 for a review). In the first camp, neoclassical growth models of the Solow-Swan or Ramsey-Cass-Koopmans types introduce human capital as an exogenous factor in aggregate production functions to help explain growth of per capita GDP (or income). These models have been used extensively to test hypotheses about convergence of incomes (relative to their steady states) across countries. Examples include Mankiw, Romer, and Weil (1992); Trondl (2001); and Barro and Sala-i-Martin (1995). Mankiw, Romer, and Weil (1992) provide a test of the textbook Solow model augmented by human capital. While cross-county tests for convergence are rare, in one case Rappaport (1999) finds real income convergence across U.S. counties. ${ }^{2}$

The second strand of macro growth models treats human capital as endogenously determined. In this camp, some view the accumulation of human capital as the key to sustained economic growth, as in Lucas (1988). To others, growth is attributable to the existing or initial stock of human capital - the source of innovations (Romer 1990) or "ability to imitate" and adopt innovations from outside the local economy (Nelson and Phelps 1966). In both the Lucas and Romer versions of the endogenous growth models, human capital leads to sustained technological progress and growth (Krueger and Lindhal 2001, pp. 1108-1109), but convergence to a steady state is not predicted by these models. A prototype empirical model takes the form of equation (1) (Krueger and Lindhal 2001, p. 1112):

$$
\Delta \log Y_{i t}=\beta_{0}+\beta_{1} \log Y_{i t-1}+\beta_{2} S_{i t-1}+\delta \Delta S+Z_{i t-1} \beta_{3}+\varepsilon
$$

where, 


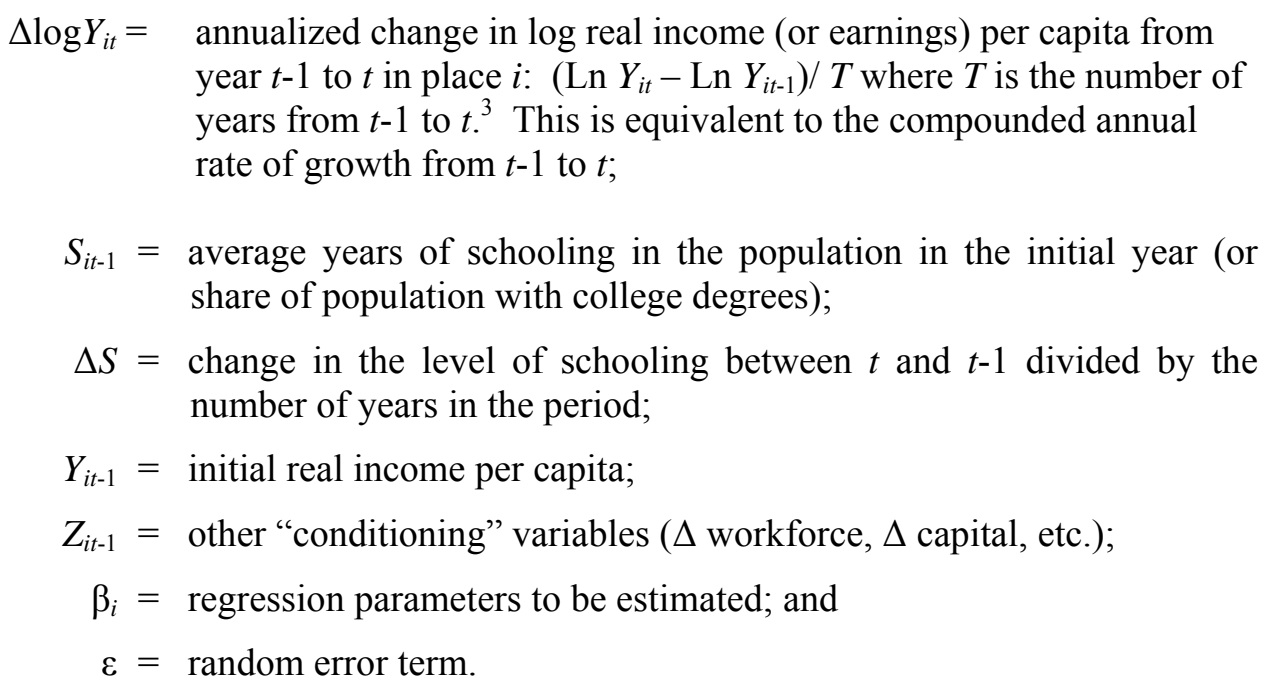

Krueger and Lindhal (2001, p. 1119) find that, across counties, change in schooling has little effect on GDP growth over short time periods (five years) but that both initial levels and change in schooling over longer time periods (10 to 20 years) have positive effects on economic growth. This finding supports models that contend it is the educational effect from initial stocks of human capital on the ability to innovate and adapt that matters to growth. However, it also lends credence to models that argue that it is the growth in human capital as a separate factor of production that boosts economic growth. Unfortunately, as in Muth (1970), a direction of causality problem is likely if higher income growth in an area is associated with faster rates of in-migration of people with higher levels of human capital. We discuss this issue in the empirical results that follow. ${ }^{4}$

\subsection{Some Data and Econometric Issues}

The mountain of empirical work estimating parameters of macro growth models across counties, and to a lesser extent across regions (e.g., states) reveals a variety of caveats and suggestions for an estimation strategy. Starting with the Krueger and Lindhal (2001) review, we note two principal issues that are pertinent to our problem of estimation of county level models: ${ }^{5}$ controls for capital stock and spatial dependence.

${ }^{2}$ Beeson-DeJong (2002) investigate convergence of population growth rates across counties of the U.S., while Simon and Nardinelli (2002) focus on employment growth in U.S. cities/MSAs.

${ }^{3}$ The growth rate, $g$, is found as: $Y_{t}=Y_{t-1} e^{g T}$ or $\ln Y_{t}-\ln Y_{t-1}=g T$ and $g=\left(\ln Y_{t}-\ln Y_{t-1}\right) / T$.

${ }^{4}$ The analogy to Muth's famous "chicken or egg" problem in jobs versus people was suggested by one of the anonymous reviewers.

${ }^{5}$ Much of the Krueger and Lindhal (2001) review concerns quality of data and measurement problems in cross-country estimation. As Krueger and Lindhal (2001, p. 1131) suggest, measurement problems are likely to much less severe across regions of the U.S. than across countries - even suggesting that regional studies might be superior to cross-country analyses for that reason. 


\subsubsection{The Stock of Physical Capital}

While the use of a capital stock variable would seem highly desirable given the aggregate production function perspective of many macro growth models, there are several econometric and data issues to consider. Krueger and Lindhal (2001, p. 1118) specify four concerns:

1. "Some authors argue that capital is endogenously determined in growth equations because investment is a choice variable and shocks to output are likely to influence the optimal level of investment. . .."

2. “. . . because of capital-skill complementarities, countries may attract more investment if they raise their level of education."

3. ". . . the growth in capital could in part pick up the effect of endogenous technological change."

4. "Reliable capital stock data over time and countries may not be available."

One practical choice is to eliminate the change in capital per worker (or beginning period capital per worker) from the model. "This can be justified in the Solow type models if a Cobb-Douglas production function is assumed and capital's share is assumed to be constant overtime and invariant across countries" (Krueger and Lindhal 2001, p. 1124). This seems unlikely for small regions like counties and, as Krueger and Lindhal note, "positive correlation between education and capital would imply that some of the increased output attributed to education ... should be attributed to capital" (Krueger and Lindhal 2001, p. 1124). This is the problem of capital-skills complementarities.

In sum, Krueger and Lindhal (2001, p. 1126) posit "lessons learned" from the growth regression literature:

1. "... change in capital has an enormous effect on a GDP growth equation, probably because of endogeneity bias."

2. "... the impact of both the level and change in schooling on economic growth is sensitive to whether the change in capital is included in the growth equation and allowed to have a coefficient that greatly exceeds capital's share."

3 “. . controlling for capital exacerbates measurement error problems."

4. ". . . when the coefficient on capital growth is constrained to equal a plausible value, changes in years of schooling are positively related to economic growth."

Fortunately, the use of county data in the U.S. ameliorates the problem of measurement error compared to data from countries with less robust national economic accounting and 
census data. On one front, this makes us more sanguine about proceeding with empirical estimates than Krueger and Lindhal (2001, p. 1126). On the other hand, measures of capital at the county level are not available, necessitating strong assumptions about fixed capital shares across types of rural counties. In our case, we control for county economic base type to reflect differing aggregate production functions and the implied role of physical capital. For example, manufacturing-based rural counties might be expected to have larger stocks of physical capital per worker than service-based economies.

\subsubsection{County Spatial Dependence}

Spatial dependence between counties means that estimates from an econometric model without a spatial lag or error correction may be biased and inconsistent if the specification fails to capture spatial structural information (Anselin 1988). One solution to the problem of spatial dependence is to construct a spatially lagged variable that can account for spatial dependence. A typical spatial autoregressive model is: ${ }^{6}$

$$
Y=\rho W Y+X \eta+e
$$

where $\rho$ is the spatial autoregressive parameter, $Y$ is a random variable with a spatial autoregressive structure, $W$ is a row standardized spatial weight matrix, $W Y$ represents the spatial lag of the dependent variable $Y, X$ is a vector of explanatory variables that are assumed to be uncorrelated with the error term, $\eta$ is a vector of regression parameters, and $e$ is the random error term. If tests reveal spatial autocorrelation in the residuals after inclusion of the spatial lag, then an option is to estimate a general spatial model that includes an error term, $\lambda W u$, in equation (2) under the assumption that the remaining errors, $e$, are normally and independently distributed with mean zero and constant variance.

We address the potential for spatial dependence in equation (1) by including a spatial lag, $W \Delta \log Y i t$, since county growth can be affected by the fortunes of nearby counties. ${ }^{7}$ For example, substantial commuting activity across proximate counties means that income by place of residence can be associated with growth or decline in nearby local labor markets. In addition, earnings by place of work will reflect both the vitality of local labor markets in a county and backward and forward linkages that county businesses might have with businesses in proximate counties.

\footnotetext{
${ }^{6}$ Rearranging (2): $(I-\rho W) Y=X \eta+e$ or $Y=(I-\rho W)^{-1} X \eta+(I-\rho W)^{-1} e$ for the general spatial autoregressive model, which allows the spatial data generating process to work through known variables, $X \eta$, and the unobserved variables, $e$ (see Lesage, 1999 for a discussion).

${ }^{7}$ Alternatively spatial dependence may be present only in the error term as we discuss in the empirical sections below.
} 


\section{INCOME GROWTH REGRESSIONS}

A Mankiw, Romer, and Weil (1992) type model adjusted for county level regressions can be written as: ${ }^{8}$

$$
\Delta \log Y_{i t}=a+\rho W \Delta \log Y_{i t}+b \log Y_{i t-1}+X \beta+\varepsilon
$$

where

$$
\begin{aligned}
& \Delta \log Y_{i t}=\text { annualized change in } \log \text { real income per capita from year } t-1 \text { to } t \text { in } \\
& \text { county } i \text {; } \\
& W \Delta \log Y_{i t}=\text { the mean growth rate in per capita income in counties that are } \\
& Y_{i t-1}=\text { initial real income per capita; and } \\
& \varepsilon=\lambda W u+e \text { for the general spatial and spatial error models reported }
\end{aligned}
$$

The $X$ vector includes the following county control variables:

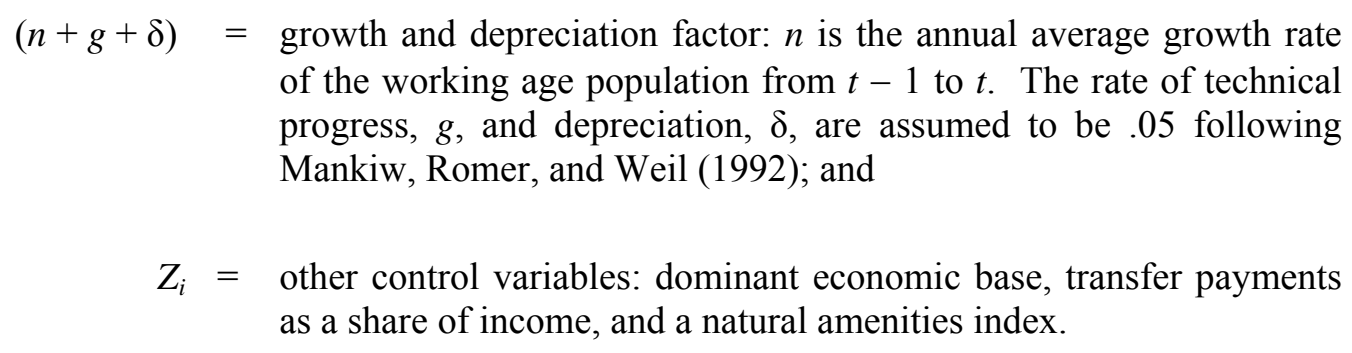

\footnotetext{
${ }^{8}$ Alternative models are developed for income in Henry, Barkley, and Li (2003). Results including growth of human capital on the right-hand side suggest strong human capital effects on income growth across counties. However, reverse causation is likely. Dropping human growth as a regressor reduces the impacts of beginning period human capital on rural growth rates. Maintaining the one-equation approach in Mankiw, Romer, and Weil (1992), we opt to delete the human capital growth rate in empirical work and leave alternative two equation models for future work.
} 
There are four main adjustments to the prototype empirical model in (1). First, the growth equation (1) is revised to capture controls for spatial dependence shown in (2). Second, tests of the joint effect of initial stocks of human capital and its accumulation over time show substantial impacts on real income growth from both human capital measures (see Henry, Barkley, and Li 2003). However, concerns over feedback from higher income growth to higher rates of human capital accumulation (reverse causation) motivated deletion of the human capital growth variable.

Third, to test for the effect that human capital might have on rural growth, we modify equation (3) to include both a rural intercept adjustment and a slope shifter for the human capital variable as shown in equations (4) and (5). The rural test in equation (4) adds an intercept dummy variable for nonmetropolitan counties $(\mathrm{NM}=1$ for nonmetro counties, 0 for metro counties) in the South and an interaction term between beginning period human capital and the nonmetro dummy.

Fourth, the other control variables differ from the county level models in (1). Investment share of local income is a component of the Mankiw, Romer, and Weil (1992) model, but since this is not available at the county level, we take this as a fixed share across counties with the same dominant economic base. We assume that this influence is captured in equation (5) through economic base intercept dummies that reflect alternative aggregate production functions. A further rationale for deleting investment, as Krueger and Lindhall (2001) find, is that inclusion of investment as a regressor is likely to lead to simultaneity bias in growth regressions on real income growth. We use share of transfer payments in personal income as a control for beginning period socioeconomic conditions - persistent poverty counties, retirement payments to the elderly, etc. Finally, we use an amenity index that captures dozens of physical and geographical features of each county (see McGranahan 1999).

Adding these adjustments, except for type of nonmetro county economic base, to the Mankiw, Romer, and Weil (1992) cross-country model yields equation (4).

$$
\begin{aligned}
& \Delta \log Y_{i t}=a_{1}+a_{2} \mathrm{NM}+\rho W \Delta \log Y_{i t}+b \log Y_{i t-1}+\beta_{1} \log S_{i, t-1}+\beta_{2} \mathrm{NM} * \log S_{i . t-1} \\
& +\Sigma B_{5 j} Z_{i j}+\varepsilon
\end{aligned}
$$

\footnotetext{
${ }^{9}$ In the human capital-augmented Solow model, with the annualized rate of income growth as the dependent variable, the annual speed of convergence to steady state is found as $\theta=-[\log (1-b)]$ where $b$ is the parameter on beginning period income per capita in the growth regression. The "half life" of convergence to the steady state - half the time between initial period $Y_{0}$ and $Y^{*}$ (the steady state level) is found as $\operatorname{Ln}(2)$ / $\theta$ (see Trondl 2001, p. 46, or Barro and Sala-i-Martin 1995, p. 37). In contrast to the Solow model, endogenous growth models can have divergence across per capita income levels that persist even if "counties have the same saving and population growth rates" (Mankiw, Romer, and Weil 1992, p. 423).
} 
If human capital endowments enhance income growth, we expect to see positive estimates for $\beta_{1}$. Moreover, if real income growth is faster in nonmetro than in metro counties from the same initial level of human capital, then we would find positive parameter estimates for $\beta_{2}$. A positive parameter on the nonmetro intercept dummy suggests that other forces (often interpreted as technical change in growth regressions) yield higher returns in nonmetro counties, given the initial level of income, human capital, and other control variables.

Since rural counties - especially in the South - often lag behind urban places in educational attainment, one might expect a larger boost to per capita incomes in rural areas than in urban areas from a given change in human capital. Moreover, the dominant economic base in a rural county might be expected to affect the ability to translate added human capital into faster real income growth - via an enhanced ability to adapt to new technology, improved learning by doing, etc. For example, rural counties dominated by farming with large shares of college educated residents might more readily adapt innovations in seed, chemicals, and machinery to generate higher net farm income compared to farm counties with few residents with a college education. In contrast, rural counties dominated by government (military bases, for example) might find real incomes that are closely tied to slow but steady adjustments in government pay scales regardless of the human capital resources in the county. If so, government counties' income growth would be less responsive to added human capital than farm counties.

To test for rural economic base effects on real income growth, we interact human capital with dummies for six economic base types defined by the Economic Research Service (ERS) in equation (5). ${ }^{10}$ These include nonmetro counties that have as a dominant economic base of type $k\left(E B_{k}\right)$ : Farming, Mining, Manufacturing, Government, Services, and Nonspecialized. Metro counties form the base of comparison for each type of rural economic base, so one can detect differences in the human capital impacts on real income growth by inspection of the $\beta_{2 k}$ parameter estimates and their corresponding statistical significance.

$$
\begin{aligned}
& \Delta \log Y_{i t}=a_{1}+\Sigma a_{2 k} E B_{k}+\rho W \Delta \log Y_{i t}+\mathrm{b} \log Y_{i t-1}+\beta_{1} \log S_{i, t-1}+\Sigma \beta_{2 k} E B_{k}{ }^{*} \log S_{i, t-1} \\
& +\Sigma B_{5 j} Z_{i j}+\varepsilon
\end{aligned}
$$

\section{EMPIRICAL RESULTS}

\subsection{Data}

We estimate equations (4) and (5) using annualized rates of real income changes from 1970 to 2000, and over the period 1980 to 2000 using a lag on initial human capital

\footnotetext{
${ }^{10}$ ERS economic base typologies cover each rural county (see Cook and Mizer 1994).
} 
as a second test for potential feedback effects. ${ }^{11}$ The selection of the 1980 to 2000 period also permits us to test whether education's role in rural income growth differed in the time period sometimes thought of as the beginning of the "New" or "Global" economy. Data are from census years, 1970, 1980, and 2000. ${ }^{12}$ Observations include all counties in 15 southern states ${ }^{13}$ for each census year. Data are from various census files as compiled by Harris, Evans, and Schwab (2001); from the Regional Economic Information System (REIS), Bureau of Economic Analysis, U.S. Department of Commerce; and from the Economic Research Service (ERS), U.S. Department of Agriculture. The authors supplement the 1970 and 1980 data provided by Harris, Evans, and Schwab (2001) with Census 2000 data. Variable definitions, means, and standard deviations are presented in Tables $1 \mathrm{~A}$ and $1 \mathrm{~B}$.

Spatial econometric models are estimated using Anselin's (1999) Spacestat 1.90 for the instrumental variable (IV) spatial lag models and the generalized method of moments (GMM) spatial error models. LeSage (1999) public domain programs for MATLAB 6.5 are used to estimate the OLS and ML estimates of spatial autoregressive, spatial error, and general spatial models. Results on key parameters vary across spatial econometric models but typically not in dramatic fashion.

\subsection{Regression Results}

Results from estimating equation (4) are displayed in Table 2A. Like Mankiw, Romer, and Weil (1992), we find conditional convergence of real per capita income growth across counties, with $b=-0.0256$ on the initial income variable in the General Spatial model (implying a half-life transition to the steady state of about 25 to 30 years). ${ }^{14}$ We also find that the spatial lag on income growth is consistently positive and highly significant in the ML estimations, suggesting that spatial autoregressive dependence is present in $\Delta \log Y_{i t}$. However, the IV estimation rejects the significance of the spatial lag, indicating that the spatial error model is preferred. Both the GMM and ML estimates of the spatial error model indicate spatially auto-correlated residuals. Again, failure to adjust for the spatial lag may lead to biased parameter estimates in models that do not include a spatial lag variable. While we did not detect substantial variation in parameters across models estimated in Table 2A, the general spatial model results reveal that the

\footnotetext{
${ }^{11}$ While contemporaneous growth in $\mathrm{HK}$ is not included as a regressor, it is still possible that counties with higher rates of real per capita income growth from 1970 to 2000 attracted people with higher levels of human capital by 1970, if these individuals anticipated the faster growth rates from 1970 to 2000. By looking at income growth from 1980 to 2000 with 1970 human capital stocks, we reduce the likelihood of this kind of potential feedback.

${ }^{12}$ A related approach (Trondl 2001) could estimate per capita income levels rather than growth for panels of 1970, 1980, 1990, and 2000 across counties in the south.

13 States include: Alabama, Arkansas, Florida, Georgia, Kentucky, Louisiana, Maryland, Mississippi, Missouri, North Carolina, Oklahoma, South Carolina, Tennessee, Texas, and Virginia.

${ }^{14}$ See footnote 10 for an explanation of how the half-life transition to the steady state is computed and a brief explanation of its meaning.
} 
TABLE 1A

Initial Year Variables, Means, and Standard Deviations for Southern States

\begin{tabular}{|c|c|c|c|c|c|c|c|}
\hline & & \multicolumn{2}{|c|}{1970} & \multicolumn{2}{|c|}{1980} & \multicolumn{2}{|c|}{2000} \\
\hline & & MEAN & STD & MEAN & STD & MEAN & STD \\
\hline POP & population & 43,428 & 105,018 & 53,026 & 128,963 & 70,414 & 181,961 \\
\hline EMP & employment by place of work & 19,611 & 54,370 & 26,402 & 78,470 & 41,639 & 126,649 \\
\hline LPOP & log population & 9.9026 & 1.0812 & 10.0900 & 1.1136 & 10.2560 & 1.2189 \\
\hline LEMP & log employment by place of work & 8.9437 & 1.1787 & 9.1729 & 1.2274 & 9.4975 & 1.3242 \\
\hline R PCPI & real income per capita & 7,827 & 2,937 & 9,141 & 2,272 & 12,347 & 2,871 \\
\hline R_PEARN & real earnings per worker & 13,349 & 2,947 & 13,497 & 3,736 & 14,305 & 3,422 \\
\hline $\log Y$ & log real income per capita & 8.9203 & 0.2806 & 9.0942 & 0.2257 & 9.3975 & 0.2129 \\
\hline LogEARN & log real earnings per worker & 9.4765 & 0.2116 & 9.4742 & 0.2679 & 9.5411 & 0.2342 \\
\hline Schooling & pop share with some college, $\%$ & 13.4755 & 5.9148 & 20.8774 & 7.6896 & 37.6281 & 10.3609 \\
\hline LogSchooling & log pop share with sone college & 2.5164 & 0.4069 & 2.9782 & 0.3430 & 3.5918 & 0.2665 \\
\hline MNF & manufacturing share of employment, $\%$ & 19.5117 & 13.0648 & 19.0220 & 12.1577 & 14.4934 & 9.7969 \\
\hline LogMNF & log manufacturing share of employment & 2.6649 & 0.9268 & 2.6804 & 0.8551 & 2.3966 & 0.8329 \\
\hline $\mathrm{TP}$ & transfer payments as share of income, $\%$ & 12.6574 & 4.7650 & 16.3278 & 5.4110 & 20.6806 & 6.9029 \\
\hline $\operatorname{LogTP}$ & log transfer payments as share of income & 2.4650 & 0.3948 & 2.7324 & 0.3630 & 2.9652 & 0.3792 \\
\hline LAND & land area (square miles) & 630 & 423 & 630 & 423 & 630 & 423 \\
\hline LAREA & log land area & 6.2845 & 0.5677 & 6.2845 & 0.5677 & 6.2845 & 0.5677 \\
\hline NEIG_POP & neighbor counties pop & 245,917 & 281,113 & 302,880 & 356,249 & 396,707 & 519,009 \\
\hline NEIG_EMP & neighbor counties emp place of work & 111,695 & 137,488 & 150,548 & 204,922 & 237,407 & 354,419 \\
\hline NEIG_PI & neighbor counties total personal income & 870,535 & $1,239,715$ & $2,768,681$ & $4,109,575$ & $10,879,924$ & $17,989,631$ \\
\hline NEIG_EARN & neighbor counties total earnings & 695,545 & $1,013,736$ & $2,081,953$ & $3,433,738$ & $7,886,465$ & $15,121,328$ \\
\hline NEIG_Y & neighbor counties real per capita income & 8,707 & 8,249 & 10,345 & 8,397 & 14,147 & 10,731 \\
\hline NEIG_REP & neighbor counties real earn per worker & 14,505 & 2,279 & 14,958 & 2,646 & 15,982 & 2,995 \\
\hline LNEIG_POP & log neighbor counties pop. & 12.0146 & 0.8717 & 12.2157 & 0.8773 & 12.4088 & 0.9548 \\
\hline LNEIG_EMP & log neighbor counties emp. & 11.1702 & 0.9176 & 11.4211 & 0.9574 & 11.7826 & 1.0443 \\
\hline LNEIG_Y & log neighbor counties real per capita income & 9.0054 & 0.2829 & 9.1878 & 0.2602 & 9.5028 & 0.2525 \\
\hline LNEIG_REP & log neighbor counties real earnings per worker & 9.5703 & 0.1537 & 9.5977 & 0.1749 & 9.6630 & 0.775 \\
\hline METRŌ & metro $=1$ & 0.2719 & 0.4451 & 0.2719 & 0.4451 & 0.2713 & 0.4448 \\
\hline NONMETRO & nonmetro $=1$ & 0.7276 & 0.4454 & 0.7276 & 0.4454 & 0.7281 & 0.4451 \\
\hline $\mathrm{F}$ & nonmetro farming-dependent $=1$ & 0.1244 & 0.301 & 0.1244 & 0.3301 & 0.1245 & 0.3302 \\
\hline
\end{tabular}




\begin{tabular}{|c|c|c|c|c|c|c|c|}
\hline \multicolumn{8}{|c|}{ Table 1A (Continued) } \\
\hline & & \multicolumn{2}{|c|}{$\underline{1970}$} & \multicolumn{2}{|c|}{$\underline{1980}$} & \multicolumn{2}{|c|}{$\underline{2000}$} \\
\hline & & MEAN & STD & MEAN & STD & MEAN & STD \\
\hline $\mathrm{G}$ & nonmetro government-dependent $=1$ & 0.0759 & 0.2650 & 0.0759 & 0.2650 & 0.0760 & 0.2651 \\
\hline MA & nonmetro manufacturing-dependent $=1$ & 0.2227 & 0.4162 & 0.2227 & 0.4162 & 0.2229 & 0.4163 \\
\hline M & nonmetro mining-dependent $=1$ & 0.0586 & 0.2349 & 0.0586 & 0.2349 & 0.0586 & 0.2350 \\
\hline $\mathrm{S}$ & nonmetro service-dependent $=1$ & 0.0766 & 0.2661 & 0.0766 & 0.2661 & 0.0767 & 0.2662 \\
\hline $\mathrm{N}$ & nonmetro nonspecialized $=1$ & 0.1699 & 0.3757 & 0.1699 & 0.3757 & 0.1700 & 0.3758 \\
\hline
\end{tabular}

\section{TABLE 1B}

Growth Rate Variables, Means, and Standard Deviations for Southern States

\begin{tabular}{llcc}
\hline & & $\mathbf{1 9 7 0 - 2 0 0 0}$ \\
\hline$\Delta \log Y$ & annualized real per capita income growth & 0.0159 & 0.0077 \\
$\Delta \log L$ & annualized population growth & 0.0129 & 0.0140 \\
$\Delta \log E$ & annualized employment growth & 0.0185 & 0.0156 \\
$W \Delta \log Y$ & spatial lag on real per capita income growth & 0.0166 & 0.0060 \\
$W \Delta \log L$ & spatial lag on population growth & 0.0133 & 0.0102 \\
$W \Delta \log E$ & spatial lag on employment growth & 0.0204 & 0.0110 \\
$\Delta \log S$ & annualized change in log schooling & 0.0358 & 0.0090 \\
\hline
\end{tabular}


spatial lag parameter, rho $(\rho)$, and the spatial error autocorrelation parameter, lambda $(\lambda)$, are both highly significant. Accordingly, we focus our discussion on results from the general spatial model - with both spatial lags and spatial error terms.

In equation (4) we capture the role of human capital in real income growth from the effect of beginning period human capital in both metro and nonmetro counties. Human capital is entered as a "linear in the logs" variable. ${ }^{15}$ As shown in Table 2A, our log measure of initial human capital has a positive, statistically significant impact on the real income growth rate in both metro counties (the parameter on the "log schooling variable," $S_{i t-1}$ in Table 2A) and in nonmetro counties (the sum of the parameters on the $S_{i t-1}$ and $\mathrm{NM}^{*} S_{i t-1}$ variables). In addition, higher initial shares of transfer payments reduce the rate of real income growth and faster income growth in proximate counties stimulates "own" county income growth (see General Spatial model in Table 2A). However, other variables do not have an important impact on real income growth after controlling for initial income, the human capital variables and growth in proximate counties.

The estimates of equation (5) are displayed in Table 2B. In this model, a proxy for physical capital - the dominant economic base type - is used in two ways to capture variation in real income growth process across types of local economies. First, different aggregate production functions are allowed through intercept dummies for each type of rural county type, with metro counties serving as the "diversified" excluded category. Second, the interaction terms between each county type and initial schooling should reflect the relative importance of human capital to the different economic bases on the rural counties (or to differing aggregate production functions).

Focusing on the General Spatial model results, we find conditional convergence and a positive spatial lag. Transfer payment shares still matter, while other non-human capital variables do not - as in Table 2A. The key parameter on the initial human capital variable for metro counties is about the same (0.0042) as before. Interestingly, the nonmetro county economic base interactions with initial human capital reveal substantial variation across the rural South in how human capital affects real per capita income growth.

${ }^{15}$ In the linear-log model (Ramanathan 2002, p. 235), the effect that increasing the share of college graduates in $1970\left(X_{1}\right)$ has on the income growth rate $(Y)$ is found as $\Delta Y=\beta_{1}(\Delta X / X)$ or $\left(\beta_{1} / 100\right) \times$ percent change in $X_{1}$ where $\beta_{1}$ is the partial regression parameter on the share of college in 1970. If $\beta_{1}$ is positive, the marginal effect of increasing $X_{1}$ on the income growth rate declines as $X_{1}$ increases. We assume a simple linear relationship between the growth rates. As Krueger and Lindhal (2001, p. 1112) note, human capital accumulation may be associated with faster "anticipated" real income growth - raising a reverse causality bias problem. Bils and Klenow (2000) find this problem for cross country models accounts for about half of the human capital effect on growth. 
TABLE 2A

Per Capita Income Growth: Metro versus Nonmetro Counties

Dependent variable: County Annual Growth Rates in Real Per Capita Income, 1970 to 2000 in the South

\begin{tabular}{|c|c|c|c|c|c|c|c|c|c|c|c|c|}
\hline \multirow{3}{*}{ Estimation Method } & \multicolumn{2}{|c|}{ Base } & \multicolumn{4}{|c|}{ Spatial Lag } & \multicolumn{4}{|c|}{ Spatial Error } & \multicolumn{2}{|c|}{ General Spatial } \\
\hline & \multicolumn{2}{|c|}{ OLS } & \multicolumn{2}{|c|}{$\begin{array}{c}\text { IV } \\
(2 S L S)\end{array}$} & \multicolumn{2}{|c|}{ ML } & \multicolumn{2}{|c|}{$\begin{array}{c}\text { GMM } \\
\text { (iterated) }\end{array}$} & \multicolumn{2}{|c|}{ ML } & \multicolumn{2}{|c|}{ ML } \\
\hline & coeff. & p-value & coeff. & $\mathrm{p}$-value & coeff. & p-value & coeff. & p-value & coeff. & $\mathrm{p}$-value & coeff. & p-value \\
\hline intercept & 0.2615 & 0.00 & 0.2582 & 0.00 & 0.2338 & 0.00 & 0.2515 & 0.00 & 0.2505 & 0.00 & 0.2446 & 0.00 \\
\hline log initial income & -0.0267 & 0.00 & -0.0265 & 0.00 & -0.0244 & 0.00 & -0.0267 & 0.00 & -0.0266 & 0.00 & -0.0256 & 0.00 \\
\hline $\begin{array}{l}\text { growth and depreciation } \\
\text { factor }\end{array}$ & 0.0011 & 0.02 & 0.0010 & 0.04 & 0.0004 & 0.28 & -0.0004 & 0.45 & -0.0002 & 0.65 & 0.0002 & 0.65 \\
\hline $\begin{array}{c}\text { log initial schooling } \\
\text { (pop-some } \\
\text { college\%) }\end{array}$ & 0.0042 & 0.00 & 0.0042 & 0.00 & 0.0041 & 0.00 & 0.0052 & 0.00 & 0.0051 & 0.00 & 0.0043 & 0.00 \\
\hline $\begin{array}{l}\text { log initial schooling } \\
\text { *nonmetro }\end{array}$ & -0.0022 & 0.00 & -0.0021 & 0.00 & -0.0014 & 0.03 & -0.0012 & 0.06 & -0.0012 & 0.06 & -0.0013 & 0.03 \\
\hline nonmetro $=1$, met $o=0$ & 0.0021 & 0.28 & 0.0019 & 0.33 & 0.0003 & 0.87 & 0.0002 & 0.89 & 0.0002 & 0.92 & 0.0001 & 0.94 \\
\hline $\begin{array}{l}\text { log transfer payments as } \\
\text { share of income }\end{array}$ & -0.0050 & 0.00 & -0.0050 & 0.00 & -0.0044 & 0.00 & -0.0037 & 0.00 & -0.0036 & 0.00 & -0.0046 & 0.00 \\
\hline natural amenity scale & -0.0001 & 0.16 & -0.0001 & 0.22 & 0.0000 & 0.76 & 0.0001 & 0.57 & 0.0000 & 0.70 & 0.0000 & 0.68 \\
\hline $\begin{array}{l}\text { rho } \\
\text { lambda }\end{array}$ & & & 0.0261 & 0.47 & 0.2300 & 0.00 & 0.4897 & 0.00 & 0.5160 & 0.00 & $\begin{array}{l}0.1670 \\
0.1170\end{array}$ & $\begin{array}{l}0.00 \\
0.00\end{array}$ \\
\hline R2-adj./Sq.Corr. & 0.6392 & & 0.6450 & & 0.6261 & & 0.6265 & & 0.7018 & & 0.6718 & \\
\hline \multicolumn{13}{|c|}{ Test for Spatial Dependence } \\
\hline J (error) & $\begin{array}{l}\text { test stat. } \\
19971\end{array}$ & p-value & $\begin{array}{l}\text { test stat. } \\
5822\end{array}$ & p-value & & & & & & & & \\
\hline $\begin{array}{l}\text { LM (error) } \\
\text { Robust LM (error) }\end{array}$ & $\begin{array}{l}199 . / 1 \\
130.83\end{array}$ & 0.00 & & & & & & & & & & \\
\hline LM (lag) & 69.72 & 0.00 & & & & & & & & & & \\
\hline Robust LM (lag) & 0.85 & 0.36 & & & & & & & & & & \\
\hline
\end{tabular}


The net effect on each of these interactions is summarized in Table 2C. Using the results from the General Spatial model (though other spatial models generally yield similar results), we find that the growth rate effect of a unit increase in initial human capital is 0.0043 in metro counties but falls to .0029 for the overall nonmetro average.

Interactions of human capital with the dominant economic base (alternative aggregate production function) show no significant initial human capital effect in mining counties. However, human capital in service-based counties has a real per capita income growth impact that exceeds the metro effect (0.0056). Other types of rural counties have somewhat smaller growth effects from added initial human capital than metro counties - but they are still statistically significant. Human capital boosts income growth by .0030 in both manufacturing and nonspecialized rural counties, by 0.0029 in government dominated counties, and 0.0020 in farm based counties of the South.

\subsection{Marginal Impacts on Income Growth from Higher Levels of Human Capital}

In Table 2D, we report marginal effects on income growth rates from a one standard deviation increase in initial human capital stock across county types. The top of Table 2D shows the results for the models described above for the 1970 to 2000 period, while the lower part of the table lists results for the 1980 to 2000 period (see the Appendix for detailed results) - each using 1970 as the initial year for the human capital stock variable.

As Simon and Nardinelli (2002) suggest, there is the possibility of feedback effects even using only initial stocks of human capital if people with higher levels of human capital anticipated where the faster growth counties would be and were drawn to those places. Using lagged human capital (1970 levels for 1980 to 2000 growth rates) should ameliorate this potential problem.

From 1970 to 2000 , the annual growth rate in metro county income is increased by .18 percentage points for a one standard deviation increase in the share of the population with at least some college in 1970. The mean college "plus" share was 17.18 percent across all metro counties in the South in 1970 with a standard deviation of 7.28 percent. This means that a one standard deviation increase in log college share represents a 42 percent increase, and would boost the annual metro real per capita income growth rate from 1.72 percent per year to 1.91 percent per year, evaluated at the mean income growth rate - about an 11 percent increase in the growth rate. ${ }^{16}$

For the average rural county in the South, the sum of the parameters on the $S_{i t-1}$ and $\mathrm{NM}^{*} S_{i t-1}$ variables is .0029 . A one standard deviation increase in the share of the population with at least some college in 1970 (4.61 percent) added to the nonmetro mean of

\footnotetext{
${ }^{16}$ Simon and Nardinelli (2002, p. 74) find a one standard deviation increase in college graduates increased city employment growth rates by about 38 percent across the U.S. from 1900 to 1986.
} 
TABLE 2B

Per Capita Income Growth: Metro versus Nonmetro Economic Base Types

Dependent Variable: County Annual Growth Rates in Real Per Capita Income, 1970 to 2000 in the South

\begin{tabular}{|c|c|c|c|c|c|c|c|c|c|c|c|c|}
\hline \multirow{3}{*}{$\begin{array}{l}\text { Model } \\
\text { Estimation Method } \\
\end{array}$} & \multirow{2}{*}{\multicolumn{2}{|c|}{$\begin{array}{l}\text { Base } \\
\text { OLS } \\
\end{array}$}} & \multicolumn{4}{|c|}{ Spatial Lag } & \multicolumn{4}{|c|}{ Spatial Error } & \multirow{2}{*}{\multicolumn{2}{|c|}{$\begin{array}{c}\text { General Spatial } \\
\text { ML }\end{array}$}} \\
\hline & & & \multicolumn{2}{|c|}{ IV (2SLS) } & \multicolumn{2}{|c|}{ ML } & \multicolumn{2}{|c|}{ GMM (iterated) } & \multicolumn{2}{|c|}{ ML } & & \\
\hline & coeff. & p-value & coeff. & p-value & coeff. & p-value & coeff. & p-value & coeff. & p-value & coeff. & p-value \\
\hline intercept & 0.2572 & 0.00 & 0.2555 & 0.00 & 0.2372 & 0.00 & 0.2542 & 0.00 & 0.2531 & 0.00 & 0.2470 & 0.00 \\
\hline log initial income & -0.0263 & 0.00 & -0.0262 & 0.00 & -0.0247 & 0.00 & -0.0269 & 0.00 & -0.0267 & 0.00 & -0.0257 & 0.00 \\
\hline growth and depreciation factor & 0.0006 & 0.21 & 0.0006 & 0.25 & 0.0002 & 0.53 & -0.0004 & 0.42 & -0.0002 & 0.65 & 0.0000 & 0.93 \\
\hline $\begin{array}{l}\text { log schooling (pop share } w / \\
\text { some college) }\end{array}$ & 0.0041 & 0.00 & 0.0041 & 0.00 & 0.0041 & 0.00 & 0.0050 & 0.00 & 0.0049 & 0.00 & 0.0042 & 0.00 \\
\hline log schooling* farm & -0.0031 & 0.01 & -0.0030 & 0.01 & -0.0018 & 0.06 & -0.0022 & 0.04 & -0.0022 & 0.05 & -0.0022 & 0.04 \\
\hline log schooling * mining & -0.0056 & 0.00 & -0.0055 & 0.00 & -0.0044 & 0.00 & -0.003 & 0.02 & -0.0033 & 0.01 & -0.0043 & 0.00 \\
\hline log schooling * manufacturing & -0.0015 & 0.13 & -0.0015 & 0.13 & -0.0014 & 0.13 & -0.0012 & 0.21 & -0.0010 & 0.30 & -0.0012 & 0.18 \\
\hline log schooling* government & -0.0013 & 0.22 & -0.0013 & 0.22 & -0.0012 & 0.24 & -0.0016 & 0.11 & -0.0015 & 0.15 & -0.0013 & 0.17 \\
\hline $\log$ schooling * service & 0.0009 & 0.52 & 0.0010 & 0.51 & 0.0012 & 0.38 & 0.0020 & 0.14 & 0.0018 & 0.18 & 0.0014 & 0.28 \\
\hline log schooling* nonspec & -0.0020 & 0.05 & -0.0020 & 0.06 & -0.0012 & 0.17 & -0.0014 & 0.14 & -0.0014 & 0.14 & -0.0012 & 0.17 \\
\hline farming & 0.0030 & 0.30 & 0.0028 & 0.35 & 0.0006 & 0.81 & 0.0018 & 0.52 & 0.0017 & 0.54 & 0.0012 & 0.66 \\
\hline mining & 0.0091 & 0.01 & 0.0088 & 0.01 & 0.0066 & 0.04 & 0.0039 & 0.24 & 0.0047 & 0.17 & 0.0064 & 0.05 \\
\hline manufacturing & 0.0014 & 0.57 & 0.0014 & 0.58 & 0.0009 & 0.69 & 0.0006 & 0.80 & 0.0003 & 0.92 & 0.0004 & 0.85 \\
\hline government & -0.0022 & 0.44 & -0.0022 & 0.44 & -0.0023 & 0.38 & -0.0005 & 0.85 & -0.0007 & 0.79 & -0.0018 & 0.47 \\
\hline service & -0.0040 & 0.30 & -0.0040 & 0.29 & -0.0046 & 0.21 & -0.0064 & 0.06 & -0.0062 & 0.08 & -0.0052 & 0.14 \\
\hline nonspecialized & 0.0019 & 0.46 & 0.0018 & 0.50 & 0.0000 & 1.00 & 0.0006 & 0.80 & 0.0006 & 0.79 & 0.0001 & 0.98 \\
\hline $\begin{array}{l}\text { log transfer payments as share } \\
\text { of income }\end{array}$ & -0.0051 & 0.00 & -0.0050 & 0.00 & -0.0046 & 0.00 & -0.0039 & 0.00 & -0.0038 & 0.00 & -0.0047 & 0.00 \\
\hline natural amenity scale & -0.0001 & 0.27 & -0.0001 & 0.31 & 0.0000 & 0.70 & 0.0000 & 0.80 & 0.0000 & 0.93 & -0.0001 & 0.56 \\
\hline rho & & & 0.0154 & 0.68 & 0.1910 & 0.00 & & & & & 0.1280 & 0.00 \\
\hline lambda & & & & & & & 0.4634 & 0.00 & 0.4680 & 0.00 & 0.1180 & 0.00 \\
\hline R2-adj./Sq.Corr. & 0.6596 & & 0.6656 & & 0.6496 & & 0.6500 & & 0.7059 & & 0.6838 & \\
\hline \multicolumn{13}{|l|}{ Test for Spatial Dependence } \\
\hline & $\begin{array}{l}\text { test } \\
\text { stat. }\end{array}$ & p-value & $\begin{array}{l}\text { test } \\
\text { stat. }\end{array}$ & p-value & & & & & & & & \\
\hline LM (error) & 141.29 & 0.00 & 48.92 & 0.00 & & & & & & & & \\
\hline Robust LM (error) & 106.00 & 0.00 & & & & & & & & & & \\
\hline LM (lag) & 38.52 & 0.00 & & & & & & & & & & \\
\hline Robust LM (lag) & 3.23 & 0.07 & & & & & & & & & & \\
\hline
\end{tabular}


TABLE $2 \mathrm{C}$

Per Capita Income Growth: Metro and Nonmetro Counties in the South LR tests for the statistical significance of the HK variables

\begin{tabular}{|c|c|c|c|}
\hline & $\begin{array}{c}\text { General } \\
\text { Spatial }\end{array}$ & & \\
\hline Model & $\underline{\text { ML }}$ & & \\
\hline Estimation Method & coefficient & LR & $\begin{array}{c}\text { Significance } \\
\text { level }\end{array}$ \\
\hline \multicolumn{4}{|l|}{ model $\mathrm{w} /$ metro and nonmetro } \\
\hline log initial schooling-pop share $w /$ college -metro & 0.0043 & & $* * * * *$ \\
\hline log initial schooling-pop share w/ college -nonmetro & 0.0029 & & $* * * * *$ \\
\hline \multicolumn{4}{|l|}{ model w/ economic bases } \\
\hline log initial schooling-pop share w/ college -metro & 0.0042 & & $* * * * *$ \\
\hline log initial schooling-pop share w/ college - farm & 0.0020 & 3.75 & $* * *$ \\
\hline log initial schooling-pop share w/ college - mining & -0.0001 & 0.01 & $*$ \\
\hline log initial schooling-pop share w/ college -manufacturing & 0.0030 & 12.50 & $* * * * *$ \\
\hline log initial schooling-pop share w/ college - government & 0.0029 & 10.16 & $* * * * *$ \\
\hline log initial schooling-pop share $w /$ college - service & 0.0056 & 18.24 & $* * * * *$ \\
\hline log initial schooling-pop share $w /$ college - nonspec. & 0.0030 & 12.56 & $* * * * *$ \\
\hline \multicolumn{4}{|c|}{$\begin{array}{l}{ }^{*} \text { Significant level }>90 \%,{ }^{* *} 10 \%<\text { significant level }<90 \%, * * * 5 \%<\text { Significant level }<10 \%, \\
* * * * 1 \%<\text { significant level }<5 \%, * * * * * \text { Significant level }<1 \% \\
\text { Likelihood Ratio (LR) test }{ }^{17}\end{array}$} \\
\hline
\end{tabular}

\footnotetext{
${ }^{17}$ The LR test statistic $=-2 \operatorname{Ln}\left(L_{R} / L_{U}\right) \sim \chi^{2}$ with degree of freedom $=1$ in our case, where $L_{R}$ and $\mathrm{L}_{\mathrm{U}}$ are the likelihood from restricted and unrestricted model estimations, respectively. For the model with metro-nonmetro category, the unrestricted model estimated: $\Delta \log Y_{i t}=\beta_{0}+\beta_{1} \log Y_{i t-1}$ $+\beta_{2} S_{\mathrm{it}-1}+\beta_{3}\left(\mathrm{~S}_{\mathrm{it}-1} *\right.$ NONMETRO $)+\beta_{4} \mathrm{Z}_{\mathrm{it}-1}+\varepsilon$. To test the significance of schooling effect on income growth for nonmetro area, we define the null hypothesis $\beta_{2}+\beta_{3}=0$ versus $\beta_{2}+\beta_{3} \neq 0$. The null can also be defined: $\beta_{2}=-\beta_{3}$. So the restricted model estimated is, $\Delta \log Y_{i t}=\beta_{0}+\beta_{1} \log Y_{i t-1}$ $+\beta_{23}\left(S_{i t-1}-S_{i t-1} *\right.$ NONMETRO $)+\beta_{4} Z_{i t-1}+\varepsilon$ If LR test static is large enough to reject the null, we can conclude that schooling has an important role in income growth for nonmetro area. The similar test procedures are used for models with economic base category.
} 
TABLE 2D

Marginal Impacts of Schooling on Income Growth (Percent of population 25 and older with at least some college) (standard deviation change, schooling)

\begin{tabular}{|c|c|c|c|c|c|c|c|c|}
\hline Year 1970-2000 & Metro & Nonmetro & Farm & Mining & Manu & Gov & Service & Nonspec. \\
\hline mean (schooling, 1970) & 17.18 & 12.09 & 12.53 & 12.43 & 11.02 & 13.24 & 13.66 & 11.83 \\
\hline one standard deviation (school, 1970) & 7.28 & 4.61 & 4.67 & 5.48 & 3.49 & 6.63 & 4.39 & 4.18 \\
\hline \% change, Std vs. Mean (school, 1970) & 42.36 & 38.10 & 37.31 & 44.09 & 31.65 & 50.09 & 32.12 & 35.38 \\
\hline regression coefficient on log year 70 school & 0.0043 & 0.0029 & 0.0020 & -0.0001 & 0.0030 & 0.0029 & 0.0056 & 0.0030 \\
\hline income growth rate(\%), 1970-2000 & 1.72 & 1.54 & 1.20 & 1.31 & 1.75 & 1.54 & 1.63 & 1.56 \\
\hline change in income growth rate(\%) & 0.18 & 0.11 & 0.07 & 0.00 & 0.09 & 0.15 & 0.18 & 0.11 \\
\hline new income growth rate(\%) & 1.91 & 1.65 & 1.27 & 1.31 & 1.85 & 1.68 & 1.81 & 1.66 \\
\hline$\%$ change in income growth rate(\%) & 10.57 & 7.16 & 6.23 & -0.34 & 5.42 & 9.45 & 11.06 & 6.81 \\
\hline Year 1980-2000 & Metro & Nonmetro & Farm & Mining & Manu & Gov & Service & Nonspec \\
\hline mean (school, 1970) & 17.18 & 12.09 & 12.53 & 12.43 & 11.02 & 13.24 & 13.66 & 11.83 \\
\hline one standard deviation (school, 1970) & 7.28 & 4.61 & 4.67 & 5.48 & 3.49 & 6.63 & 4.39 & 4.18 \\
\hline \% change, Std vs. Mean (school, 1970) & 42.36 & 38.10 & 37.31 & 44.09 & 31.65 & 50.09 & 32.12 & 35.38 \\
\hline regression coefficient on log year 70 school & 0.0052 & 0.0036 & 0.0056 & 0.0001 & 0.0034 & 0.0032 & 0.0078 & 0.0016 \\
\hline income growth rate(\%), 1980-2000 & 1.54 & 1.51 & 1.62 & 0.61 & 1.69 & 1.51 & 1.45 & 1.51 \\
\hline change in income growth rate(\%) & 0.22 & 0.14 & 0.21 & 0.00 & 0.11 & 0.16 & 0.25 & 0.06 \\
\hline new income growth rate(\%) & 1.76 & 1.64 & 1.83 & 0.61 & 1.80 & 1.67 & 1.70 & 1.57 \\
\hline$\%$ change in income growth rate(\%) & 14.28 & 9.04 & 13.00 & 0.73 & 6.29 & 10.58 & 17.20 & 3.83 \\
\hline
\end{tabular}


12.09 percent increases annual rural growth rates, evaluated at the overall mean, from 1.54 percent to 1.65 percent - about a 7 percent increase in the growth rate. These increases in real income growth rates support the contention that the initial level of human capital matters to subsequent growth.

\subsection{Rural Economic Base Effects}

Since rural counties are often dominated by a few basic industries - farming, manufacturing, mining, etc., we hypothesized that human capital impacts might differ by type of economic base. As noted above, this is also consistent with the notion that the aggregate production function may vary substantially across counties with differing economic bases.

Economic base alters the effect that human capital has on income growth, as shown in Table 2D. At one extreme, a one standard deviation increase in initial human capital in nonmetro counties dominated by mining has no effect on real per capita income growth rates while rural counties with services as the dominant base get the largest growth boost - from 1.63 percent to 1.81 percent, an 11.06 percent increase - a bit larger than the metro effect. In between, government counties obtain a 9.45 percent "return" while farming (6.23 percent), nonspecialized (6.81 percent), and manufacturing (5.42 percent) fall between the extremes.

Results for the 1980 to 2000 growth regressions with 1970 human capital stock, shown in the bottom of Table 2D, reinforce the findings for the 1970 to 2000 period. In fact, except for nonspecialized rural counties, there are larger growth premiums from beginning 1970 human capital stock from 1980 to 2000 than for the earlier period. This suggests that human capital endowments have become increasingly important to real per capita income growth in the rural South in more recent decades.

\subsection{How Do the County Results Compare to Cross-Country Findings?}

Krueger and Lindahl (2001) find for the 1965-85 period that the initial human capital parameter is 0.026 and the change in human capital parameter estimate is 0.614 in crosscountry regressions where physical capital and workforce variables are excluded from the model. When they add physical capital and labor to the regression, the initial human capital parameter estimate drops to 0.01 and the change in human capital parameter declines to .178. These findings suggest the need to account for physical capital and labor. We attempt to do so in equation (5) by including county population growth rates ${ }^{18}$ and a proxy for physical capital - the dominant economic base in the county.

\footnotetext{
${ }^{18}$ Population growth is the annual average growth rate of the working age population for the 19702000 or 1980-2000 time periods, as discussed in development of the Mankiw, Romer, and Weil (1992) type regression in equation (4).
} 
Results in Henry, Barkley, and Li (2003), which include growth in human capital as a regressor, strongly mirror those of the basic Krueger and Lindahl (2001) growth regressions. Moreover, parameter estimates are consistent with the Mankiw, Romer, and Weil (1992) findings. Deletion of the human capital growth variable, however, reduces the magnitude of the initial human capital impact on income growth rates in our sample of counties.

When we exclude the growth rate of human capital accumulation in this model, we find that the initial stock of human capital is still important to real per capita income growth both in metro and nonmetro counties - with the exception of mining-dependent counties - in the South. If the economic base typologies are not a good proxy for physical capital variation across types of rural counties, some of the human capital effects may reflect omitted physical capital as suggested by Krueger and Lindahl (2001). However, the potential for reverse causality has been purged from the estimates in Henry, Barkley, and Li (2003) by excluding the growth rate of human capital and in estimates with lagged initial human capital. ${ }^{19}$

\section{SUMMARY}

County per capita income growth rates from 1970 to 2000 across the South are affected by the initial stock of human capital. The share of the " 25 plus" population in a county that has at least some college is our proxy for initial levels of human capital. The human capital influences are entered in standard growth regressions that are modified to capture spatial economic structure at the county level. Thus, they include spatial lags and spatial error adjustments. As is the custom in growth regressions, beginning period real income is used to test for conditional convergence (which we also fail to reject across all models).

The growth regressions show that counties with higher 1970 levels of human capital experienced greater real per capita income growth from 1970 to 2000 and from 1980 to 2000. While metro counties consistently get more of a growth "premium" from a given increment to human capital, nonmetro counties also grow faster with more human capital. Generally, rural growth impacts from added human capital are about one-half to twothirds of the metro growth premiums. Within the rural South, service-based counties generally fare best from added human capital, while mining-based counties gain the least.

\footnotetext{
${ }^{19}$ In Temple's (1999, p. 142) review of the Mankiw, Romer, and Weil (1992) type model, he notes: "Most recent growth researchers have included population growth as a variable of subsidiary interest, perhaps in the manner suggested by MRW, and then noted a weak negative correlation between it and growth of per capita income. This raises some endogeneity concerns, although one might think of causality running to population growth from the level of per capita income rather than its rate of growth." Since we use the rate of growth of per capita income as the dependent variable rather than its level, endogeneity problems seem unlikely with our use of population growth as a regressor.
} 
human capital in the nonmetro counties of the South yields a 7 percent to 9 percent faster real per capita income growth rate. Controlling for the dominant economic base in the rural county, we find no effect from added human capital on real per capita income growth in mining counties. However, service-based counties expand from 11 percent to 17 percent faster from a one standard deviation addition to human capital stock in 1970 . One standard deviation additions to human capital stock in 1970 boost real per capita income growth rates in farm counties by 6 percent to 13 percent, in manufacturing counties from 5 percent to 6 percent, in government counties by 9 percent to 11 percent, and in nonspecialized counties by 4 percent to 7 percent. These are substantial returns to human capital in the rural South. Alternative measures of human capital that reflect "quality" need to be considered. Still, it is fair to speculate that added human capital investment in the rural South is more than the usual political hyperbole - it looks like human capital is, in fact, a key to success in the rural south.

\section{REFERENCES}

Anselin, L., 1988. Spatial Econometrics: Methods and Models. Kluwer Academic Publishers: Dordrect.

1999. Spatial Data Analysis with SpaceStat and ArcView, Workbook (3 ${ }^{\text {rd }}$ Edition). Dept. of Agricultural and Consumer Economics, University of Illinois: Urbana, IL.

Barkley, D.L. and M.S. Henry, 1998. "The Role of Local School Quality in Rural Employment and Population Growth," Review of Regional Studies 28(1), 81-102.

Barro, R and X. Sala-i-Martin, 1995. Economic Growth. McGraw-Hill: New York.

Beeson, P. and D. Dejong, 2002. "Divergence," Contributions to Macroeconomics 2(1), Article 6 (http://www.bepress.com/bejm).

Bils, M. and P. Klenow, 2000. "Does Schooling Cause Growth?" American Economic Review 90, 1160-83.

Cook, P. and K. Mizer, 1994. "Revised ERS County Typology, An Overview," Rural Development Research Report No. 89. Economic Research Service, U.S. Department of Agriculture: Washington, D.C.

Harris, A.R, W. Evans, and R. Schwab, 2001. "Education Spending in an Aging America," Journal of Public Economics 81(1), 449-472.

Henry, M., D. Barkley, and H. Li, 2003. "Education and Nonmetropolitan Development in the South," conference paper presented at Promoting the Economic and Social Vitality of Rural America, The Role of Education, New Orleans, April 14-15.

Krueger, A. and M. Lindhal, 2001. "Education for Growth, Why and For Whom?" Journal of Economic Literature 39, 1101-1136.

Ladd, H.F. and S.E. Murray, 2001. "Intergenerational Conflict Reconsidered, County Demographic Structure and the Demand for Public Education," Economics of Education Review 20, 343-357.

LeSage, J.P., 1999. The Theory and Practice of Spatial Econometrics, unpublished manuscript available at http://www.spatial-econometrics.com.

Lucas, R., 1988. "On the Mechanics of Economic Development," Journal of Monetary Economics 22, 3-42. 
Mankiw, G., D. Romer, and D. Weil, 1992. "A Contribution to The Empirics of Economic Growth," Quarterly Journal of Economics 107, 407-437.

McGranahan, D., 1999. "Natural Amenities Drive Population Change," Agricultural Economic Report 781. Economic Research Service, U.S. Department of Agriculture: Washington, D.C.

Muth, R., 1970. "Migration: Chicken or Egg?" The Southern Economic Journal 37, 295-306.

Nelson, R. and E. Phelps, 1966. "Investment in Humans, Technological Diffusion, and Economic Growth," American Economic Review 61, 69-75.

Poterba, J.M., 1997. "Demographic Structure and the Political Economy of Public Education," Journal of Policy Analysis and Management 16, 48-66.

Ramanathan, R., 2002. Introductory Econometrics with Applications, Fifth Ed. Harcourt: New York.

Rappaport, J., 1999. Local Growth Empirics. Center for International Development, Harvard University, CID Working Paper No. 23.

Romer, P., 1990. “Endogenous Technological Change," Journal of Political Economy 98(part 2), 71-102.

Simon, C.J. and C. Nardinelli, 2002. "Human Capital and the Rise of American Cities," Regional Science and Urban Economics 32, 59-96.

Temple, J., 1999. "The New Growth Evidence," Journal of Economic Literature 37, 112-156.

Tondl, G., 2001. Convergence After Divergence? Regional Growth in Europe. Springer Verlag: New York. 